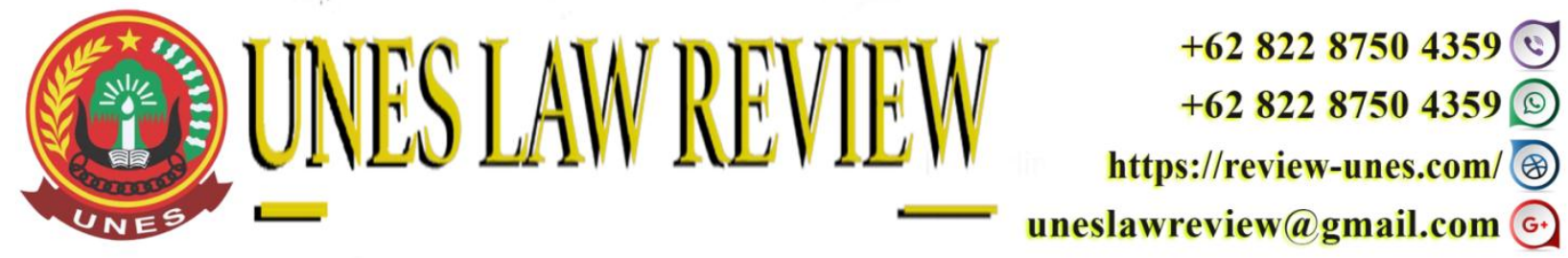

DOI: https://doi.org/10.31933/unesrev.v3i2

Diterima: 25/12/2020, Diperbaiki: 29/12/2020, Diterbitkan: 30/12/2020

\title{
PENERAPAN UNSUR TINDAK PIDANA MELAKUKAN PENJUALAN BARANG TIDAK SESUAI DENGAN SPESIFIKASI BARANG DALAM KEMASAN OLEH PELAKU USAHA (STUDI PADA SUBDIT I INDAGSI DITRESKRIMSUS POLDA SUMBAR)
}

\author{
Yoga Sugama \\ Magister Ilmu Hukum, Universitas Ekasakti, Padang, Indonesia \\ Email: yogasugama@gmail.com
}

Corresponding Author: Yoga

\begin{abstract}
The case of fraudulent acts, especially the problem of the contents in the packaging that is not in accordance with what is described in the packaging label is regulated in Article 382 of the Criminal Code. One of them is handled by the West Sumatra Regional Police's Ditreskrimsus. This is in accordance with the Police Report Number: LP / 303 / A / XI / 2019 / Spkt-Sbr, dated 4 November 2019, with the alleged criminal act intentionally including or making information or statements that are misleading or not in accordance with the actual conditions or incorrect item label found on Tuesday, October 1, 2019. used in this study is a normative juridical approach supported by an empirical juridical approach. From the results of the research and discussion, it can be concluded that: First, the elements of a criminal act of selling goods not in accordance with the specifications of goods in packaging by business actors in Sub-Directorate I Indagsi Ditreskrimsus Polda West Sumatra, are: Article 144 Jo Article 100 paragraph (2) Law Number 18 of 2012 on Food, and Article 62 paragraph (1) of Law Number 8 the Year 1999 concerning Consumer Protection. Second, the application of the elements of a criminal act of selling goods that are not in accordance with the specifications of packaged goods by business actors at the Sub-Directorate I of the Directorate General of Criminal and Criminal Investigation of the West Sumatra Regional Police is Article 144 Jo Article 100 paragraph (2) of Law Number 18 the Year 2012 concerning Food, by looking at a) Anyone, b) Intentionally, and c) provide information or statements that are untrue or misleading on labels. As well as Article 62 paragraph (1) of Law Number 8 the Year 1999 concerning Consumer Protection, with the following elements: a) not in accordance with the conditions; b) guarantee, features or efficacy; and c) as stated in the label, etiquette or description of the goods and/or services. Third, the obstacles encountered by the Submit I Indagsi Ditreskrimsus Polda West Sumatra are internal and external constraints. There are internal obstacles: a) political intervention that makes this case stop; and b) given SP3. Meanwhile, the external constraints are a) The modus operandi of the perpetrator is always changing; b) officials from related institutions who are less cooperative; and c) lack of
\end{abstract}


socialization to the community, the efforts made in overcoming the obstacles have been adjusted to the needs of external and internal constraints.

Kata Kunci: Tindak Pidana, Penjulan, Barang, Spesifikasi Barang

\section{PENDAHULUAN}

Pembangunan serta perkembangan perekonomian pada umumnya terhadap berbagai kemajuan yang terjadi pada bidang teknologi, industri, ekonomi maupun perdagangan, mengakibatkan semakin banyak permasalahan yang terjadi di Negara kita, khususnya adalah permasalahan mengenai perlindungan konsumen di dalam bidang perindustrian dan perdagangan nasional yang telah menghasilkan berbagai variasi barang dan/jasa yang dapat dikonsumsi oleh masyarakat. Dengan adanya globalisasi dan perdagangan bebas yang didukung oleh berbagai bentuk kemajuan teknologi, telekomunikasi dan informatika telah memperluas terhadap ruang gerak arus transaksi barang sehingga barang dan atau jasa yang ditawarkan menjadi bervariasi (Eli Wuria Dewi, 2015). Kondisi seperti ini, pada satu sisi memberikan manfaat bagi konsumen karena kebutuhan barang dan atau jasa yang diinginkan dapat terpenuhi. Namun kondisi dan fenomena tersebut pada sisi lainnya dapat mengakibatkan kedudukan pelaku usaha dan konsumen menjadi tidak seimbang, dimana konsumen berada pada posisi yang lemah. Konsumen menjadi objek aktifitas bisnis untuk meraup keuntungan yang sebesar-besarnya oleh pelaku usaha melalui kiat promosi, cara penjualan, serta penerapan perjanjian standar yang merugikan konsumen (Gunawan Widjaja Ahmad Yani, 2003).

Barang yang ditawarkan oleh pelaku usaha antara lain yaitu produk pangan. Bermacammacam produk pangan dipasaran sangat menguntungkan bagi konsumen, sebab semakin besar kebebasan yang dimilikinya untuk dapat memilih produk pangan yang diinginkan dan membandingkannya dengan produk pangan lain yang berkualitas sesuai dengan kebutuhan dan keadaan keuangan konsumen. Pangan merupakan salah satu hal yang paling penting bahkan sangat pokok dan tidak dapat ditinggalkan maupun digantikan dengan yang lain di dalam kehidupannya sehari-hari, hal itu dikarenakan tanpa adanya makanan atau minuman yang dikonsumsi oleh manusia maka mereka tidak akan dapat aktif dan produktif di dalam menjalankan aktivitasnya (Janus Sidabalok, 2014). Produk makanan dan minuman yang memiliki mutu yang bagus dan layak untuk dikonsumsi serta sesuai dengan standar mutu keamanan pangan sangat dibutuhkan oleh masyarakat atau konsumen bagi kelangsungan hidup mereka. Dengan demikian keamanan pangan merupakan salah faktor yang sangat penting dan wajib diperhatikan oleh konsumen dalam memilih produk makanan yang hendak dikonsumsi agar tidak membahayakan kesehatan dan keselamatan hidupnya sendiri. Pangan yang dikonsumsi oleh konsumen paling tidak harus memenuhi beberapa syarat seperti sehat, aman, dan halal, selain itu pangan tersebut juga harus memenuhi persyaratan kualitas serta cita rasa sehingga jika dikonsumsi tidak akan menyebabkan gangguan kesehatan bahkan mengancam keselamatan jiwa konsumen (Yusuf Shofie, 2005).

Perbuatan curang dalam menjalankan usaha tersebut dapat dilakukan oleh para produsen dengan cara pencantuman label pangan yang tidak sesuai dengan barang atau jasa yang diproduksinya yang mengakibatkan persaingan curang. Label yang tidak sesuai dan atau menyesatkan berakibat buruk terhadap perkembangan kesehatan dan keselamatan jiwa konsumen. Pelaku usaha (produsen) yang melakukan pencantuman label yang tidak sesuai, tidak jelas, dan tidak jujur merupakan penyebab kerugian konsumen karena tidak adanya itikad baik dari pelaku usaha di dalam memberikan informasi atas produk yang diproduksi dan 
diperdagangkannya (Yusuf Shofie, 2005). Dalam Pasal 1 Undang-undang Nomor 18 Tahun 2012 tentang Pangan, disebutkan bahwa: "Pangan adalah segala sesuatu yang berasal dari sumber hayati dan air, baik yang diolah, yang diperuntukan sebagai makanan atau minuman bagi konsumsi manusia, termasuk bahan tambahan pangan, bahan baku pangan, dan bahan lain yang digunakan dalam proses penyiapan, pengolahan, dan atau pembuatan makan dan minuman". Dalam hubungannya dalam masalah label, khususnya label pangan maka masyarakat perlu memperoleh hak atas informasi yang benar, jelas, dan jujur mengenai kondisi dan jaminan barang dan atau jasa sebagaimana yang telah tercantum di dalam Pasal 4 huruf c Undang Undang Nomor 8 Tahun 1999 Tentang Perlindungan Konsumen. Dari informasi pada label, konsumen secara tepat dapat menentukan pilihan sebelum membeli dan atau mengkonsumsi pangan. Tanpa adanya informasi yang jelas maka kecurangan- kecurangan dapat terjadi. Dalam Undang-undang Nomor 8 Tahun 1999 tentang Perlindungan Konsumen, pengaturan pelabelan produk pangan diatur di dalam Pasal 8 ayat (1) huruf f yang berbunyi: (1) Pelaku usaha dilarang memproduksi dan/atau memperdagangkan barang dan/atau jasa yang: Tidak sesuai dengan janji yang dinyatakan dalam label, etiket, keterangan, iklan atau promosi penjualan barang dan atau jasa tersebut.

Ketentuan yang dirumuskan di dalam Pasal 8 ayat (1) huruf f ini, sangatlah berkaitan dengan apa yang telah diatur dalam Peraturan Pemerintah Nomor 69 Tahun 1999 Tentang Label dan Iklan Pangan. Di dalam Pasal 1 ayat (3) PP nomor 69 tahun 1999 ditentukan bahwa yang dimaksud dengan label pangan adalah: "Setiap keterangan mengenai pangan yang berbentuk gambar, tulisan, kombinasi keduanya atau bentuk lain yang disertakan pada pangan, dimasukan ke dalam, ditempelkan pada atau merupakan bagian kemasan pangan, yang selanjutnya dalam Peraturan Pemerintah ini disebut dengan Label" Mengingat fungsi label yang sangat penting, maka setiap produk pangan yang dalam bentuk kemasan diwajibkan mencantumkan label sebagaimana yang telah ditetapkan di dalam Pasal 3 Peraturan Pemerintah Nomor 69 Tahun 1999 Tentang Label dan Iklan Pangan yang menyatakan: (1) Label sebagaimana dimaksud dalam Pasal 2 ayat (1) berisikan keterangan mengenai pangan yang bersangkutan; (2) Keterangan sebagaimana dimaksud pada ayat (1) sekurang-kurangnya. a. Nama produk; b. Daftar bahan yang digunakan; c. Berat bersih atau isi bersih; d. Nama dan alamat pihak yang memproduksi atau memasukan ke dalam wilayah Indonesia; e. Tanggal, bulan, dan tahun kadaluwarsa. Seiring dengan berkembangnya zaman, banyak masalah pangan yang telah terjadi. Para Pelaku Usaha dalam hal melakukan persaingan usahannya dapat melakukan suatu perbuatan negatif atau yang disebut dengan perbuatan curang. Perbuatan curang dalam menjalankan usaha tersebut diatur juga di dalam Pasal 382 KUHP yang dirumuskan sebagai perbuatan yang bersifat menipu untuk memperdayakan masyarakat atau seseorang tertentu (M.Sudradjat Bassar, 1984). Pasal 382 KUHP menjelaskan sebagai berikut: "Barang siapa untuk mendapatkan, melangsungkan, atau mempertahankan hasil perdagangan atau perusahaan milik sendiri atau orang lain, melakukan perbuatan curang untuk menyesatkan khalayak umum atau seseorang tertentu, diancam jika perbuatan itu dapat menimbulkan kerugian bagi konkuren-konkurennya atau konkurenkonkuren orang lain itu, karena persaingan curang, dengan pidana penjara paling lama 1 (satu) tahun 4 (empat) bulan atau pidana denda paling banyak Rp.13.000 ( tiga belas ribu rupiah)". Pasal 382 KUHP ini ditunjukan kepada pelaku usaha yang berbuat curang dalam menjalankan usahanya. Dengan kata lain, perbuatan seseorang pelaku usaha yang melakukan tindakan curang dalam menjalankan usahanya dapat digolongkan sebagai tindak pidana. Perbuatan ini menggambarkan keadaan hasil produksi perusahaan yang bertentangan dengan kebenaran (Moch Anwar, 1990). 
Kasus perbuatan curang terutama masalah isi dalam kemasan yang tidak sesuai dengan apa yang diterangkan dalam label kemasan, sampai hari ini masih ditangani oleh Ditreskrimsus Polda Sumbar. Hal ini sesuai dengan Laporan Polisi Nomor: LP/303/A/XI/2019/Spkt-Sbr, tanggal 4 November 2019, dengan adanya Dugaan tindak pidana dengan sengaja mencantumkan atau membuat keterangan atau pernyataan yang menyesatkan atau tidak sesuai dengan kondisi yang sebenarnya atau tidak benar pada label barang yang ditemukan pada hari Selasa tanggal 1 Oktober 2019 sekira pukul 14.00 WIB yang bertempat di pabrik PT. Agrimitra Utama Persada Jalan Raya Padang-Bukittinggi Km. 51 Korong Tarok Kepala Ilalang Kecamatan 2 x 11 Kayu Tanam Kabupaten Padang Pariaman yang memproduksi dan memperdagangkan Air Minum Dalam Kemasan (AMDK) merek SMS dengan cara mencantumkan atau membuat keterangan pada label "SMS air minum berasal dari mata air pegunungan Singgalang-Sumatera Barat". Akan tetapi pada kenyataannya air yang digunakan PT. Agrimitra Utama Persada untuk memproduksi AMDK merek SMS menggunakan air PDAM Kab. Padang Pariaman yang bersumber dari mata air Lubuk Bonta Kab. Padang Pariaman, sebagaimana dimaksud dalam Pasal 144 Juncto Pasal 100 ayat (2) Undang-undang Nomor 18 Tahun 2012 tentang Pangan dan atau Pasal 62 ayat (1) Juncto Pasal 8 ayat (1) huruf d Undang-undang Nomor 8 Tahun 1999 Tentang Perlindungan Konsumen, sehubungan dengan Laporan Polisi Nomor: LP/303/A/XI/2019/Spkt-Sbr, tanggal 4 November 2019.

\section{METODE PENELITIAN}

Pendekatan yang digunakan dalam penelitian ini adalah pendekatan yuridis normatif sebagai pendekatan utama, di dukung pendekatan yuridis empiris. Pendekatan yuridis normatif digunakan untuk melihat ketentuan - ketentuan hukum yang terkait dengan penerapan unsur tindak pidana terhadap pelaku usaha yang melakukan penjualan barang tidak sesuai dengan spesifikasi barang dalam kemasan sedangkan pendekatan yuridis empiris digunakan untuk melihat bekerjanya aturan hukum tersebut dalam prakteknya di masyarakat (Darmadi Prapto Pamungkas, 2018:136).

\section{HASIL DAN PEMBAHASAN}

\section{Unsur Tindak Pidana Melakukan Penjualan Barang Tidak Sesuai dengan Spesifikasi Barang dalam Kemasan Oleh Pelaku Usaha Pada Subdit I Indagsi Ditreskrimsus Polda Sumbar}

Keberhasilan suatu bisnis sebagian besar diukur juga berdasarkan nilai dan norma yang berlaku dalam masyarakat itu, termasuk nilai dan norma yang berlaku dalam masyarakat itu, tidak hanya ditentukan oleh kiat bisnis murni, melainkan juga penghayatan terhadap nilai dan norma sosial. Dalam bisnis memang ada persaingan yang ketat, tetapi tidaklah benar pandangan bahwa pengusaha yang mematuhi aturan moral akan berada dalam posisi yang tidak menguntungkan bahkan tersingkir. Dasi sudut pandang pebisnis sendiri semakin disadari bahwa bisnis yang berhasil adalah bisnis yang memperhatikan norma-norma moral. Pengusaha sadar bahwa bisnisnya akan hancur kalau konsumen (langganan), tidak mempercayai lagi produk yang dihasilkan dari bisnisnya, demikian juga jika mitra bisnisnya dirugikan melalui perbuatan curang sebagaimana diatur dalam Pasal 379a KUHP.

Ada beberapa faktor yang menyebabkan palaku bisnis melakukan perbuatan curang yang dapat dibagi ke dalam dua sisi, yaitu dari sisi intern pelaku usaha itu sendiri, dan dari sisi ekstern. 
Secara intern, faktor penyebab atau alasan pelaku usaha melakukan perbuatan curang, diantaranya yaitu: 1) Lemahnya Sumber Daya Manusia (SDM); 2) Sikap atau rasionalisasi untuk membenarkan tindakan fraud; 3) Kurangnya kesadaran moral utilitarian (moral yang berkaitan dengan memaksimumkan hal terbaik bagi orang sebanyak mungkin); 4) Menurunnya formalism etis (moral yang berfokus pada maksud yang berkaitan dengan perilaku dan hak tertentu; dan 5) Pandangan yang salah dalam menjalankan bisnis, dimana tujuan utama bisnis adalah mencari keuntungan semata, bukan kegiatan sosial.

Berikut akan disajikan pengaturan curang di dalam Kitab Undang-undang Hukum Pidana (KUHP) Indonesia (Wahyu Musa Gunawan, 2020): 1) Pasal 378, Barang siapa dengan maksud untuk menguntungkan diri sendiri atau orang lain secara melawan hukum, dengan memakai nama palsu atau martabat palsu, dengan tipu muslihat, ataupun rangkaian kebohongan, menggerakkan orang lain untuk menyerahkan barang sesuatu kepadanya, atau supaya memberi hutang maupun menghapuskan piutang, diancam karena penipuan dengan pidana penjara paling lama empat tahun; 2) Pasal 379, Perbuatan yang dirumuskan dalam pasal 378, jika barang yang diserahkan itu bukan ternak dan harga daripada barang, hutang atau piutang itu tidak lebih dan dua puluh lima rupiah diancam sebagai penipuan ringan dengan pidana penjara paling lama tiga bulan atau pidana denda paling banyak dua ratus lima puluh rupiah; 3) Pasal 379a, Barang siapa menjadikan sebagai mata pencarian atau kebiasaan untuk membeli barang-barang, dengan maksud supaya tanpa pembayaran seluruhnya memastikan penguasaan terhadap barang-barang itu untuk diri sendiri maupun orang lain, diancam dengan pidana penjara paling lama empat tahun; 4) Pasal 380 (1) Diancam dengan pidana penjara paling lama dua tahun delapan bulan atau pidana denda paling banyak lima ribu rupiah: barang siapa menaruh suatu nama atau tanda secara palsu di atas atau di dalam suatu hasil kesusastraan, keilmuan, kesenian atau kerajinan, atau memalsu nama atau tanda yang asli, dengan maksud supaya orang mengira bahwa itu benarbenar buah hasil orang yang nama atau tandanya ditaruh olehnya di atas atau di dalamnya tadi; barang siapa dengan sengaja menjual, menawarkan, menyerahkan, mempunyai persediaan untuk dijual atau memasukan ke Indonesia, hasil kesusastraan, keilmuan,kerajinan, yang di dalam atau di atasnya atau tanda yang palsu, atau yang nama yang asli telah dipalsu, seakan-akan itu orang yang nama atau tandanya telah ditaruh secara palsu tadi; 5) Pasal 381, Barang siapa dengan tipu muslihat menyesatkan penanggung asuransi keadaan-keadaan yang berhubungan dengan pertanggungan sehingga disetujui perjanjian, hal mana tentu tidak akan setidak-tidaknya tidak dengan syarat-syarat demikian, jika diketahuinya keadaan-keadaan sebenarnya diancam dengan pidana penjara paling lama satu tahun empat bulan; 6) Pasal 382, Barang siapa dengan maksud untuk menguntungkan diri sendiri atau oranglain secara melawan hukum, atas kerugian penanggung asuransi atau pemegang surat bodemerij yang sah, menimbulkan kepada suatu barang yang dipertanggungkan terhadap bahaya kebakaran, atau mengaramkan, mendamparkan, menghancurkan, atau membikin tak dapat dipakai, kapal yang dipertanggungkan atau yang muatannya maupun upah untuk pengangkutan muatannya yang dipertanggungkan ataupun yang atasnya telah diterima uang bodemerij diancam dengan pidana penjara paling lama lima tahun; 7) Pasal 382 bis, Barang siapa untuk mendapatkan, melangsungkan atau memperluas hasil 
perdagangan atau perusahaan milik sendiri atau orang lain, melakukan perbuatan curang untuk menyesatkan khalayak umum atau seorang tertentu, diancam, jika perbuatan itu dapat menimbulkan kerugian bagi konkuren-konkurennya atau konkuren-konkuren orang lain, karena persaingan curang, dengan pidana penjara paling lama satu tahun empat bulan atau pidana denda paling banyak tiga belas ribu lima ratus rupiah; 8) Pasal 383, Diancam dengan pidana penjara paling lama satu tahun empat bulan, seorang penjual yang berbuat curang terhadap pembeli: 1) karena sengaja menyerahkan barang lain daripada yang ditunjuk untuk dibeli; 2) mengenai jenis, keadaan atau jumlah barang yang diserahkan, dengan menggunakan tipu muslihat; 9) Pasal 383 bis, Seorang pemegang konosemen yang sengaja mempergunakan beberapa eksemplar dan surat tersebut dengan titel yang memberatkan, dan untuk beberapa orang penerima, diancam dengan pidana penjara paling lama dua tahun delapan bulan; 10) Pasal 384, Perbuatan yang dirumuskan dalam pasal 383, diancam dengan pidana penjara paling lama tiga bulan atau denda paling banyak dua ratus lima puluh rupiah, jika jumlah keuntungan yang di peroleh tidak lebih dan dua puluh lima rupiah; 11) Pasal 385, Diancam dengan pidana penjara paling lama empat tahun: barang siapa dengan maksud menguntungkan diri sendiri atau orang lain secara melawan hukum, menjual, menukarkan atau membebani dengan credietverband sesuatu hak tanah yang belum bersertifikat, sesuatu gedung, bangunan, penanaman atau pembenihan di atas tanah yang belum bersertifikat, padahal diketahui bahwa yang mempunyai atau turut mempunyai hak di atasnya adalah orang lain; barang siapa dengan maksud yang sama menjual, menukarkan, atau membebani dengan credietverband, sesuatu hak tanah yang belum bersertifikat yang telah dibebani credietverband, atau sesuatu gedung, bangunan, penanaman atau pembenihan di atas tanah yang juga telah dibebani demikian, tanpa memberitahukan tentang adanya beban itu kepada pihak yang lain; barang siapa dengan maksud yang sama mengadakan credietverband mengenai sesuatu hak tanah yang belum bersertifikat, dengan menyembunyikan kepada pihak lain bahwa tanah yang berhubungan dengan hak tadi sudah digadaikan; barang siapa dengan maksud yang sama, menggadaikan atau menyewakan tanah dengan hak tanah yang belum bersertifikat, padahal diketahui bahwa orang lain yang mempunyai atau turut mempunyai hak atas tanah itu; barang siapa dengan maksud yang sama, menjual atau menukarkan tanah dengan hak tanah yang belum bersertifikat yang telah digadaikan, padahal tidak diberitahukannya kepada pihak yang lain bahwa tanah itu telah digadaikan; barang siapa dengan maksud yang sama, menjual atau menukarkan tanah dengan hak tanah yang belum bersertifikat untuk suatu masa, padahal diketahui, bahwa tanah itu telah disewakan kepada orang lain untuk masa itu juga; 13) Pasal 386, (1) Barang siapa menjual, menawarkan atau menyerahkan barang makanan, minuman atau obat-obatan yang diketahuinya bahwa itu dipalsu, dan menyembunyikan hal itu, diancam dengan pidana penjara paling lama empat tahun. (2) Bahan makanan, minuman atau obat-obatan itu dipalsu, jika nilainya atau faedahnya menjadi kurang karena sudah dicampur dengan sesuatu bahan lain; 14) Pasal 389, Barang siapa dengan maksud untuk menguntungkan diri sendiri atau orang lain secara melawan hukum, menghancurkan, memindahkan, membuang atau membikin tak dapat dipakai sesuatu yang digunakan untuk menentukan batas pekarangan, diancam dengan pidana penjara paling lama dua tahun delapan bulan; 15) Pasal 390, Barang 
siapa dengan maksud untuk menguntungkan diri sendiri atau orang lain secara melawan hukum, dengan menyiarkan kabar bohong yang menyebabkan harga barang-barang dagangan, dana-dana atau suratsurat berharga menjadi turun atau naik diancam dengan pidana penjara paling lama dua tahun delapan bulan; 16) Pasal 391, Barang siapa menerima kewajiban untuk, atau memberi pertolongan pada penempatan surat hutang sesuatu negara atau bagiannya, atau sesuatu lembaga umum, sero, atau surat hutang sesuatu perkumpulan, yayasan atau perseroan, mencoba menggerakkan khalayak umum untuk pendaftaran atau penyertaannya, dengan sengaja menyembunyikan atau mengurangkan keadaan yang sebenarnya, atau dengan membayangbayangkan keadaan yang palsu, diancam dengan pidana penjara paling lama empat tahun; 17) Pasal 392, Seorang pengusaha, seorang pengurus atau komisaris perseroan terbatas, maskapai andil Indonesia atau koperasi, yang sengaja mengumumkan daftar atau neraca yang tidak benar, diancam dengan pidana penjara paling lama satu tahun empat bulan; 18) Pasal 393, (1) Barang siapa memasukkan ke Indonesia tanpa tujuan jelas untuk mengeluarkan lagi dan Indonesia, menjual, menawarkan, menyerahkan, membagikan atau mempunyai persediaan untuk dijual atau dibagibagikan, barang-barang yang diketahui atau sepatutnya harus diduganya, bahwa pada barangnya itu sendiri atau pada bungkusnya dipakaikan secara palsu, nama, firma atau merek yang menjadi hak orang lain atau untuk menyatakan asalnya barang, nama sebuah tempat tertentu, dengan ditambahkan nama atau firma yang khayal, ataupun pada barangnya sendiri atau pada bungkusnya ditirukan nama, firma atau merek yang demikian sekalipun dengan sedikit perubahan, diancam dengan pidana penjara paling lama empat bulan dua minggu atau pidana denda paling banyak sembilan ribu rupiah. (2) Jika pada waktu melakukan kejahatan belum lewat lima tahun sejak adanya pemidanaan yang menjadi tetap, karena kejahatan semacam itu juga, dapat dijatuhkan pidana penjara paling lama sembilan bulan; 19) Pasal 393 bis, (1) Seorang pengacara yang sengaja memasukkan atau menyuruh masukkan dalam surat permohonan cerai atau pisah meja dan ranjang, atau dalam surat permohonan pailit, keterangan-keterangan tentang tempat tinggal atau kediaman tergugat atau penghutang, padahal diketahui atau sepatutnya harus diduganya bahwa keterangan-keterangan itu bertentangan dengan yang sebenarnya, diancam dengan pidana penjara paling lama satu tahun. (2) Diancam dengan pidana yang sama ialah si suami (istri) yang mengajukan gugatan atau si pemiutang yang memasukkan permintaan pailit, yang sengaja memberi keterangan palsu kepada pengacara yang dimaksudkan dalam ayat pertama; 20) Pasal 394, Ketentuan pasal 367 berlaku bagi kejahatan-kejahatan yang dirumuskan dalam bab ini, kecuali yang dirumuskan dalam ayat kedua pasal 393 bis, sepanjang kejahatan dilakukan mengenai keterangan untuk mohon cerai atau pisah meja dan ranjang; 21) Pasal 395 (1) Dalam hal pemidanaan berdasarkan salah satu kejahatan yang dirumuskan dalam bab ini, hakim dapat memerintahkan pengumuman putusannya dan yang bersalah dapat dicabut haknya untuk menjalankan pencarian ketika kejahatan dilakukan. (2) Dalam hal pemidanaan berdasarkan salah satu kejahatan yang dirumuskan dalam pasal 378, 382, 385, 387, 388, 393 bis, dapat dijatuhkan pencabutan hak-hak berdasarkan pasal 35 No. 1 - 4 . 


\section{Unsur-unsur Tindak Pidana Terhadap Pelaku Usaha yang Melakukan Penjualan Barang Tidak Sesuai dengan Spesifikasi Barang dalam Kemasan Pada Ditreskrimsus Polda Sumbar}

Keberhasilan suatu bisnis sebagian besar diukur juga berdasarkan nilai dan norma yang berlaku dalam masyarakat itu, termasuk nilai dan norma yang berlaku dalam masyarakat itu, tidak hanya ditentukan oleh kiat bisnis murni, melainkan juga penghayatan terhadap nilai dan norma sosial. Dalam bisnis memang ada persaingan yang ketat, tetapi tidaklah benar pandangan bahwa pengusaha yang mematuhi aturan moral akan berada dalam posisi yang tidak menguntungkan bahkan tersingkir. Dasi sudut pandang pebisnis sendiri semakin disadari bahwa bisnis yang berhasil adalah bisnis yang memperhatikan norma-norma moral. Pengusaha sadar bahwa bisnisnya akan hancur kalau konsumen (langganan), tidak mempercayai lagi produk yang dihasilkan dari bisnisnya, demikian juga jika mitra bisnisnya dirugikan melalui perbuatan curang sebagaimana diatur dalam Pasal 379a KUHP.

Ada beberapa faktor yang menyebabkan palaku bisnis melakukan perbuatan curang yang dapat dibagi ke dalam dua sisi, yaitu dari sisi intern pelaku usaha itu sendiri, dan dari sisi ekstern. Secara intern, faktor penyebab atau alasan pelaku usaha melakukan perbuatan curang, diantaranya yaitu: 1) Lemahnya Sumber Daya Manusia (SDM); 2) Sikap atau rasionalisasi untuk membenarkan tindakan fraud; 3) Kurangnya kesadaran moral utilitarian (moral yang berkaitan dengan memaksimumkan hal terbaik bagi orang sebanyak mungkin); 4) Menurunnya formalism etis (moral yang berfokus pada maksud yang berkaitan dengan perilaku dan hak tertentu; dan 5) Pandangan yang salah dalam menjalankan bisnis, dimana tujuan utama bisnis adalah mencari keuntungan semata, bukan kegiatan sosial.

Faktor penyebab atau alasan pelaku usaha melakukan perbuatan curang, diantaranya yaitu: 1) Ketentuan peraturan perundang- undang yang belum memberikan perlindungan hukum secara maksimal terhadap pelaku bisnis yang dirugikan; 2) Lemahnya pemahaman penegak hukum berkaitan dengan kegiatan bisnis sehingga ada beberapa perbuatan yang telah memenuhi unsur tindak pidana tetapi tidak dapat dilakukan penegakkan hukumnya; 3) Persaingan usaha yang semakin ketat, memacu pelaku bisnis untuk menang dalam persaingan melalui cara-cara yang bersifat curang dalam mengejar kepentingan ekonominya. Persaingan adalah proses sosial yang melibatkan individu atau kelompok yang saling berlomba dan berbuat sesuatu untuk mencapai kemenangan tertentu; 4) Kondisi ekonomi. Dalam dunia bisnis, pasang surut keuntungan menjadi suatu hal yang yang sangat diperhatikan, karena jika suatu produksi tidak disambut baik oleh konsumen dengan daya beli masyarakat, maka produsen tidak mendapat keuntungan, dan bahkan dapat bangkrut.

Sebagaimana telah dijelaskan di atas bahwa perbuatan curang dalam kegiatan bisnis adalah mencari keuntungan pribadi tanpa melihat aspek halal/haram, sehingga penguasaan barang yang menjadi objek jual-beli dilakukan secara melawan hukum karena dilakukan tanpa pembayaran, yang berdampak merugikan pihak lain baik secara materi maupun immaterial. Guna mencegah dampak negatif perbuatan curang dalam kegiatan bisnis maka perlu penegakkan hukum. 
Adapun unsur-unsur tindak pidana terhadap pelaku usaha yang melakukan penjualan barang tidak sesuai dengan spesifikasi barang dalam kemasan pada Ditreskrimsus Polda Sumbar, adalah sebagau berikut: 1) Pasal 144 Jo Pasal 100 ayat (2) Undang-Undang Nomor 18 Tahun 2012 tentang Pangan. Pasal 100 ayat (2) "Setiap orang dilarang memberikan keteragan atau pernyataan yang tidak benar dan/atau menyesatkan pada label " Pasal 144 "Setiap orang yang dengan sengaja memberikan keterangan atau pernyataan yang tidak benar atau menyesatkan pada label sebagaimana dimaksud dalam pasal 100 ayat (2) dipidana dengan pidana penjara paling lama 3 (tiga) tahun atau denda paling banyak Rp.6.000.000.000,- (enam milyar rupiah)"; dan 2) Pasal 62 ayat (1) Undang Undang Republik Indonesia Nomor 8 Tahun 1999 Tentang Perlindungan Konsumen, dengan unsur sebagai berikut "Pelaku usaha yang melanggar ketentuan sebagaimana dimaksud dalam Pasal 8, Pasal 9, Pasal 10, Pasal 13, Pasal ayat (2), Pasal 15, Pasal 17 ayat (1) huruf $a$, huruf $b$, huruf $c$, huruf e, ayat (2) dan Pasal 18 dipidana dengan pidana penjara paling lama 5 (lima) tahun atau pidana denda paling banyak Rp.2.000.000.000,- (dua miliar rupiah). Pasal 8 ayat huruf d "tidak sesuai dengan kondisi, jaminan, keistimewaan atau kemanjuran sebagaimana dinyatakan dalam label, etiket atau keterangan barang dan atau/jasa tersebut".

Terhadap pelaku yang memproduksi dan memperdagangkan Air Minum Dalam Kemasan (AMDK) merek SMS dengan cara mencantumkan atau membuat keterangan pada label "SMS air minum berasal dari mata air pegunungan Singgalang-Sumatera Barat" akan tetapi pada faktanya air yang digunakan PT. Agrimitra Utama Persada untuk memproduksi AMDK merek SMS menggunakan air PDAM Kab. Padang Pariaman yang bersumber dari mata air Lubuk Bonta Kab. Padang Pariaman dapat melanggar Pasal 144 Jo Pasal 100 ayat (2) Undang-Undang Republik Indonesia Nomor 18 Tahun 2012 tentang Pangan dan atau Pasal 62 ayat (1) Jo Pasal 8 ayat (1) huruf d Undang-Undang Nomor 8 Tahun 1999 Tentang Perlindungan Konsumen yang secara hukum dipertanggung jawabkan oleh Direktur PT.Agrimitra Utama Persada atas nama Tersangka Soehinto Sadikin.

\section{KESIMPULAN}

Adapun kesimpulan dalam penelitian ini adalah sebagai berikut ini, yaitu: 1) Unsurunsur tindak pidana terhadap pelaku usaha yang melakukan penjualan barang tidak sesuai dengan spesifikasi barang dalam kemasan pada Ditreskrimsus Polda Sumbar adalah 1) Pasal 144 Juncto Pasal 100 ayat (2) Undang-undang Nomor 18 Tahun 2012 tentang Pangan, dan 2) Pasal 62 ayat (1) Undang Undang Nomor 8 Tahun 1999 Tentang Perlindungan Konsumenl dan 2) Penerapan unsur tindak pidana melakukan penjualan barang tidak sesuai dengan spesifikasi barang dalam kemasan oleh pelaku usaha pada Subdit I Indagsi Ditreskrimsus Polda Sumbar adalah Pasal 144 Jo Pasal 100 ayat (2) Undang-Undang Nomor 18 Tahun 2012 tentang Pangan, dengan melihat a) Setiap orang, b) Dengan sengaja, dan c) memberikan keterangan atau pernyataan yang tidak benar atau menyesatkan pada label. Serta Pasal 62 ayat (1) Undangundang Nomor 8 Tahun 1999 Tentang Perliindungan Konsumen, dengan unsur sebagai berikut: 
a) tidak sesuai dengan kondisi; b) jaminan, keistimewaan atau kemanjuran; dan c) sebagaimana dinyatakan dalam label, etiket atau keterangan barang dan atau/jasa tersebut”.

\section{DAFTAR PUSTAKA}

Darmadi Prapto Pamungkas, Efektivitas Penyidikan Tindak Pidana Penambangan Emas Tanpa Izin Di Kabupaten Solok Selatan (Studi pada Direktorat Reserse Kriminal Khusus Kepolisian Daerah Sumatera Barat, UNES Law Riview, Volume 1, Issue 2, Desember 2018.

Eli Wuria Dewi, Hukum Perlindungan Konsumen, Cetakan Pertama, Graha Ilmu, Yogyakarta, 2015.

Gunawan Widjaja Ahmad Yani, Hukum Tentang Perlindungan Konsumen, Cetakan Ketiga, PT Gramedia Pustaka Umum, Jakarta, 2003.

Janus Sidabalok, Hukum Perlindungan Konsumen di Indonesia, Cetakan Ketiga, PT Citra Aditya Bakti, Medan, 2014.

Laporan Polisi Nomor: LP/303/A/XI/2019/Spkt-Sbr.

Moch Anwar, Hukum Pidana Bagian Khusus (KUHP Buku II ) Jilid 1, Cetakan VI, Citra Aditya Bakti, 1990.

M.Sudradjat Bassar, Tindak-Tindak Pidana Tertentu di Dalam Kitab Undang - Undang Hukum Pidana, Remadja Karya CV , Cetakan Pertama, Bandung, 1984.

Wahyu Musa Gunawan, Apa yang dimaksud dengan Perbuatan Curang?, https://www.dictio.id/t/apa-yang-dimaksud-dengan-perbuatan-curang/3533, diakses pada tanggal 12 November 2020.

Yusuf Shofie, Perlindungan Konsumen dan Instrumen-Instrumen Hukumnya, Citra Aditya Bakti, Bandung, hlm. 15.

Undang-Undang Republik Indonesia Nomor 8 Tahun 1999 Tentang Perlindungan Konsumen.

Undang-Undang Republik Indonesia Nomor 18 Tahun 2012 tentang Pangan.

Peraturan Pemerintah Nomor 69 Tahun 1999 Tentang Label dan Iklan Pangan. 